\title{
Sea cliff instability susceptibility at regional scale: a statistically based assessment in the southern Algarve, Portugal
}

\author{
F. M. S. F. Marques ${ }^{1}$, R. Matildes ${ }^{2}$, and P. Redweik ${ }^{2}$ \\ ${ }^{1}$ University of Lisbon, Faculty of Sciences, Centre of Geology and Department of Geology, Lisbon, Portugal \\ ${ }^{2}$ University of Lisbon, Faculty of Sciences, Centre of Geology and Department of Geographical Engineering, \\ Geophysics and Energy, Lisbon, Portugal
}

Correspondence to: F. M. S. F. Marques (fsmarques@fc.ul.pt)

Received: 1 March 2013 - Published in Nat. Hazards Earth Syst. Sci. Discuss.: 17 May 2013

Revised: 25 October 2013 - Accepted: 5 November 2013 - Published: 9 December 2013

\begin{abstract}
Sea cliff evolution is dominated by the occurrence of slope mass movements of different types and sizes, which are a considerable source of natural hazard, making their assessment a relevant issue in terms of human loss prevention and land use regulations. To address the assessment of the spatial component of sea cliff hazards, i.e. the susceptibility, a statistically based study was made to assess the capacity of a set of conditioning factors to express the occurrence of sea cliff failures affecting areas located along their top.

The study was based on the application of the bivariate information value and multivariate logistic regression statistical methods, using a set of predisposing factors for cliff failures, mainly related to geology (lithology, bedding dip, faults) and geomorphology (maximum and mean slope, height, aspect, plan curvature, toe protection), which were correlated with a photogrammetry-based inventory of cliff failures that occurred in a $60 \mathrm{yr}$ period (1947-2007). The susceptibility models were validated against the inventory data using standard success rate and ROC curves, and provided encouraging results, indicating that the proposed approaches are effective for susceptibility assessment. The results obtained also stress the need for improvement of the predisposing factors to be used in this type of study and the need for detailed and systematic cliff failure inventories.
\end{abstract}

\section{Introduction}

Slope mass movements, which include rockfalls, toppling and different types of landslides, are the dominant and more visible process of sea cliff retreat (Trenhaile, 1987;
Sunamura, 1992), a significant source of natural hazard, and a constraint for human activities and safe land use in cliffed coastal areas (e.g. Moore and Griggs, 2002). The extent and economic significance of this problem tend to increase along time, due to a general context of growing occupation of coastal areas and the large extent of cliffed and rocky shorelines, which correspond to $1 / 3$ of the world's coastlines (Emery and Kuhn, 1982; Bird, 2000). The economic value of land in coastal areas tends to be very high, as a result of increasing demand for exceptional location building areas for houses and beach and leisure resorts. There are also issues related to the presence, near the cliff top, of urban areas and also the conservation of archaeological and historical heritage (e.g. Bromhead and Ibsen, 2006; Carrasco et al., 2007). In spite of the obvious economic and social relevance of the problem, sea cliff and rock coasts have received comparatively low research attention in comparison with fast evolution sandy shorelines (Naylor et al., 2010).

Cliffs with global average retreat velocities in the range of a few decimetres per year to several metres per year are the most commonly covered in the literature, with lower retreat rate cliffs receiving much less attention. This is partly due to the difficulties in monitoring an episodic, comparatively low frequency event-based process located in highly irregular and frequently inaccessible locations. In fact, most low retreat rate sea cliffs also correspond to difficult access, highly irregular and steep slope surfaces, poorly represented in aerial photographs and maps, making their accurate monitoring a difficult task. 
There is some evidence supporting the need for a separation between soft cliffs (e.g. Dong and Guzzetti, 2005; Marques, 2008) with mean cliff retreat rates typically higher than $0.1 \mathrm{~m} \mathrm{yr}^{-1}$, and strong to intermediate strength cliffs with mean retreat rates lower than $0.1 \mathrm{~m} \mathrm{yr}^{-1}$. The former are mainly composed by overconsolidated soils or very soft rocks as chalk (e.g. Dornbush et al., 2008), with failures occurring frequently in direct relation to periods of cliff toe direct attack by waves, while the latter are mainly composed of rock masses, where direct wave attack is not directly related to or followed by cliff failure.

Some attempts have been made to provide conceptual frameworks for evolution prediction, to improve the more common approaches which rely on simple extrapolation of past cliff or shoreline evolution data to the future, but focusing mainly on fast retreating cliffs (Lee et al., 2001, 2002; Hall et al., 2002; Walkden and Hall, 2005). For low retreat rate cliff hazard estimation or assessment, the published work is very scarce and includes expert-based classification of indicators of near future instability (e.g. De Pippo et al., 2008), attempts to characterize the role of sets of conditioning factors, also weighted and combined according to local experience or expert opinion (Del Río and Gracia, 2008; Nunes et al., 2009), and use of Bayesian probabilistic models to forecast future cliff evolution based on past cliff retreat data and expert opinion on a limited set of conditioning factors (Milheiro-Oliveira, 2007; Hapke and Plant, 2010). One of the common shortcomings of these approaches lies in the non-objective assessment of the relative importance of the selected conditioning factors or indicators of future instability. In spite of the difficulties of acquiring geotechnical data accurate enough to be representative of the strength variations of the rock masses that compose the cliffs, approaches have been made using physically based slope stability evaluation methods, including different types of cliff instability (e.g. Fall et al., 2006), or specifically for cliffs mainly composed of clays (Castedo et al., 2013). One of the most common shortcomings of these approaches lies in the limited or absent validation of results using standard methods.

While the recent developments in cliff evolution monitoring techniques, mainly based on terrestrial or airborne LIDAR and digital photogrammetry, are providing new and detailed cliff evolution data on a local (Rosser et al., 2007; Young et al., 2009; Dewez et al., 2013; Katz and Mushkin, 2013) and regional (Young et al., 2011) scale, regionally based hazard studies which could support land use planning and hazard prevention measures are still at an undesirable qualitative and unobjectively assessed level, which is not compatible with straightforward management of coastal areas. In fact, the lack of standardized techniques and methods to support land use regulations in cliffed coastal areas provides the grounds for increased conflict potential between planning authorities and land owners or real estate promoters.
According to their relative location, cliff failure impacts on structures and people may affect the areas located near the cliff top, the cliff face, and the areas located near the cliff toe. The processes affecting each one of these areas have significant differences, with near cliff top retreat being the result of retrogression due to mass movement occurrence, while near toe areas are mainly affected by failure debris or block motion. The cliff faces may be affected by a combination of the two processes (e.g. Young et al., 2009).

The hazards induced in cliff faces and near the toes are very important, especially for beach support structures and people, but are restricted to the areas where these elements are present, being very small or negligible in plunging cliffs or difficult access cliff faces and toes. As examples of strong negative impacts, in Portugal, in 2006, two tourists were killed by a $6 \mathrm{~m}$-high cliff toppling failure, in 2009, another low-height $(13 \mathrm{~m})$ cliff toppling failure at Maria Luísa beach (Algarve) caused 5 fatalities (Teixeira, 2009; Marques and Andrade, 2009), and two months later, in Tenerife, a cliff rockfall caused another fatality. The common factor in these accidents is the relatively small scale of the failures, yet with high impact in terms of life loss. The hazards induced near the cliffs top may mainly affect structures, and are thus a concern for land use regulations and planning, both on a regional and local scale, and apply to the whole extension of cliffs in a given region.

Sea cliffs are usually highly irregular surfaces, where direct observation and study are frequently very difficult or nearly impossible. They also tend to be formed by soil and rock masses with complex strength variations, which make the application of physically based hazard assessments very arduous and expensive work to be carried at regional scale of analysis, with exceptions corresponding to studies carried out in fairly homogeneous and weak rock masses such as chalk (e.g. Günther and Thiel, 2009). As an alternative, and considering the relevance of cliff failures for hazard prevention and risk mitigation, statistically based methods seem more convenient approaches to hazard assessment, due to the inherent complexity of the natural environment to study.

For landslides in non-coastal areas, a complete hazard assessment includes the space, time (Varnes, 1984) and magnitude components (Guzzetti et al., 2005), with the first, designated as susceptibility, being usually the less difficult to deal with and the one which is more frequently assessed. Transposing this concept to sea cliffs results that, the susceptibility of the occurrence of cliff failures corresponds to the propensity of a given area for being affected by these phenomena, based solely on terrain conditions (Soeters and Van Westen, 1996), without any implication of the time component, i.e. time frequency or recurrence periods. In statistically based approaches, the terrain conditions correspond to a set of predisposing factors which statistically correlate with the occurrence of landslides, with the correlations being assessed using various bivariate or multivariate statistical techniques (Guzzetti et al., 2005). 


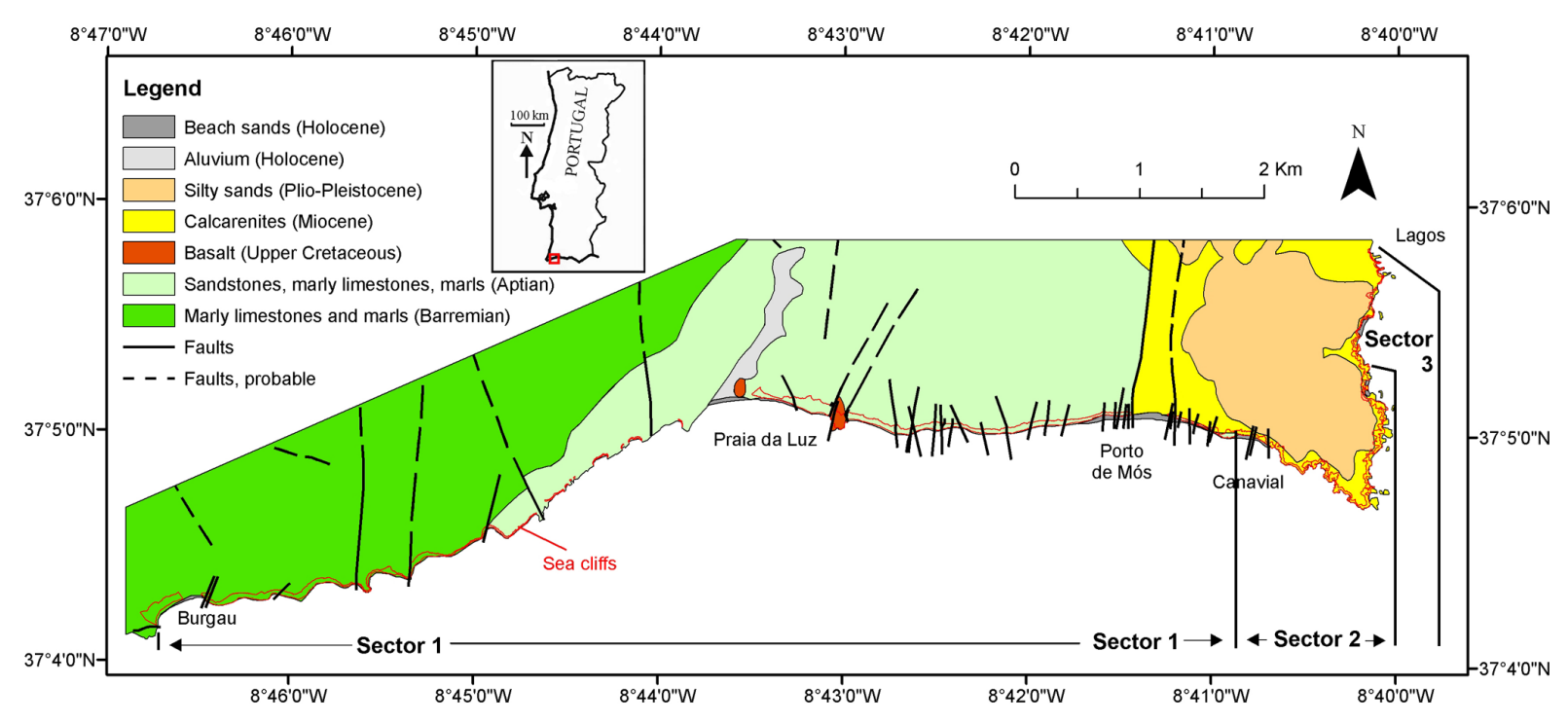

Fig. 1. Localization and main lithological units, faults and sea cliff extent (red lines) in the study area. Sectors defined according to space frequency of cliff failures and corresponding planimetric area lost at the cliff top and lithology (Fig. 2).

To address the problems involved in the assessment of the spatial component of sea cliff hazards in low retreat rate cliffs, i.e. the susceptibility of a given sector of cliffs being affected by failures which cause cliff top retreat, based solely on the spatial predisposing factors and without implications for the magnitude or time components of the phenomena, a statistically based study was performed along the top of the sea cliffs of the Burgau-Lagos coastal section (southwestern Algarve, Portugal). The study was based on an aerial digital photogrammetry systematic inventory of cliff retreat events covering a $60 \mathrm{yr}$ period (1947-2007), which included special procedures to enable the extraction of accurate data from old aerial photographs, and validated by systematic stereo photograph interpretation, helped by oblique aerial photographs observation and field surveys, and a complete set of conditioning factors which are obtainable with a degree of labour compatible with studies at regional scale. The statistical methods selected for this study, which have been applied with success to landslide susceptibility assessment, were the simple bi-variate information value method (Yin and Yan, 1988) and the multi-variate logistic regression method. The results obtained are compared with the inventory data using standard success rate curves and receiver operating characteristic curves (ROC), which enable an objective assessment of the adequacy of the susceptibility models computed.

\section{Setting}

The $15 \mathrm{~km}$-long Burgau-Lagos coastal section is located in SW Algarve (Portugal) (Fig. 1) and is composed of a $10.8 \mathrm{~km}$-long WSW-ENE, W-E and WNW-ESE trending section exposed to SW and SE main directions of storms, and a $4.1 \mathrm{~km}$-long highly irregular coastline $\mathrm{N}-\mathrm{S}$ section which is more sheltered and only affected by SE storm waves. The cliffs in the studied coastal section have a widely variable morphology, expressed in cliff height, cross profile and plan contour variations, and also lithological composition. The geology and geomorphology of the cliffs are described in detail in Marques (1997), together with a systematic inventory of cliff failures for the period 1947-1991, compiled using aerial photograph-based simplified methods (Marques, 2006). From west to east (Fig. 1), the cliffs sections are composed by Rocha et al. (1983): (a) Cretaceous (Barremian) marls, alternating marls and marly limestones; (b) Cretaceous (Aptian) sandstones, marls, and marly limestones alternating with marls cut by a late Cretaceous basaltic pipe; (c) Miocene weak calcarenites affected by numerous sinkholes which are filled with Plio-Pleistocene silty sands.

The geological structure of the study area is dominated by horizontal or gently dipping E or SE bedding. The structure in the area near Burgau is the most disturbed by tectonics: westwards of the village, the predominantly marly beds are folded and cut by faults, while eastwards, along one hundred metres, the alternating beds of marly limestones and marls are cut by faults and dip up to $25^{\circ} \mathrm{SW}$. Eastwards and until Praia da Luz, the Cretaceous bed structure corresponds to a monocline sloping of $6^{\circ}$ to $10^{\circ} \mathrm{SE}$. Eastwards of Praia da Luz, the Cretaceous marls and marly limestones alternating with marls beds slope generally less than $6^{\circ}$ E. Eastwards of Porto de Mós, the Cretaceous alternating marly limestones and marls which form the lower part of the cliffs are near horizontal but cut by several faults, and the overlying Miocene calcarenites are near horizontal but deeply affected by old 
karst features, mainly sinkholes which were filled by PlioPleistocene (PQ) reddish silty sands that also form an extensive cover in the eastern part of the study area (Fig. 1).

The cliff height varies between $6 \mathrm{~m}$ and more than $100 \mathrm{~m}$, with varied cross-profile slopes, from approximately $30^{\circ}$ sloping near linear profiles in marls to $60^{\circ}$ to $90^{\circ}$ slope angles in the alternating marly limestones and marls, and near vertical with frequent overhanging sections in the Miocene calcarenites and Cretaceous sandstones. The plan contour of the cliffs is quite regular in the Cretaceous rocks, while in the Miocene calcarenites the marine erosion of the sandy fillings of the karst sinkholes generated an extremely complex plan contour, with a succession of stacks, capes and very small bays.

\section{Methods}

The statistical methods used in this study include the bivariate information value method (Yin and Yan, 1988) and the multivariate logistic regression method (Cox, 1958, Hosmer and Lemeshow, 2000), applied to a set of predisposing factors mainly related to geology and geomorphology, which were correlated with an inventory of past cliff failures. The predisposing factors were selected considering the need to provide a complete description of geological and geomorphological constraints, which are usually considered as relevant in conditioning the occurrence of sea cliff failures and, simultaneously, could be obtained with an acceptable level of work at a regional scale. According with these conditions, the predisposing factors selected included geological and geomorphological aspects (major lithological units; geological structure, i.e. bedding dip in relation to the cliff faces; presence of faults; presence and type of natural cliff toe protection features) and morphometric aspects derived from a $2 \mathrm{~m}$ grid DTM obtained by processing of $1: 2000$ scale topographic with source data of 2002 (cliff height; mean cliff slope angle; maximum cliff slope angle; aspect, plan curvature).

\subsection{Susceptibility assessment}

\subsubsection{Information value}

The sea cliff failure inventory relations with the conditioning factors selected were assessed first using a simple bivariate statistical method of Bayesian inspiration, the information value method (Yin and Yan, 1988), which has been applied successfully for landslide susceptibility assessment (Yin and Yan, 1988; Wu et al., 2000; Zêzere, 2002). The use of this method requires that each factor is divided into classes, with each one corresponding to a variable. The information value $I_{i}$ of each variable $X_{i}$ is (Yin and Yan, 1988):

$I_{i}=\log \frac{S_{i} / N_{i}}{S / N}$ where $S_{i}$ is the number of terrain units with cliff failures of a given type in the units with the variable $X_{i}, N_{i}$ is the number of terrain units with the variable $X_{i}, S$ is the total number of terrain units with cliff failures of the same type, and $N$ is the total number of terrain units in the study area. The positive values of $I_{i}$ indicate that the variable is positively correlated with the possibility of occurrence of cliff failures; the negative ones indicate that the variable (or property) is associated with low susceptibility: for example, a very strong rock mass with widely spaced discontinuities is likely to have a strong negative $I_{i}$, being a lithological group with low susceptibility to cliff failure. The near-zero values indicate that the variable is not significant in terms of susceptibility ranking.

The total information value $I_{j}$ for a given terrain unit $j$ is:

$I_{j}=\sum_{i=1}^{m} X_{j i} \cdot I_{i}$

where $m$ is the number of variables, $X_{j i}$ is 0 if the variable is not present in the terrain unit $j$, or 1 if the variable is present.

This statistical method enables an objective assessment of the susceptibility, based only on the spatial distribution of the predisposing factor classes (variables) and on the presence or absence of cliff failures in each terrain unit. The main limitation of this method results from its bivariate character, i.e. it does not take into account correlations that may exist between variables. In this study, this method was mainly used because of its simplicity and also because it enables a direct evaluation of the results of the classification of variables.

\subsubsection{Logistic regression}

The sea cliff failure inventory relations with the conditioning factors selected were also assessed using the multivariate logistic regression method (Hosmer and Lemeshow, 2000), which consists of the regression of a dichotomic-dependent variable ( 0 without instabilities, 1 with instabilities) with a set of explanatory independent variables which may be continuous, categorical or dichotomic. The relation between instability occurrence in a given terrain unit and the set of explanatory variables is:

$$
S=\frac{1}{\left(1+e^{-\Psi}\right)} \quad 0 \leq S \leq 1,
$$

where $S$ (from 0 to 1 ) is the probability of a given terrain being in the group of the units affected by instabilities. $\Psi$ is the logit, which is linearly related to the independent variables

$$
\begin{aligned}
\Psi & =\log \left(\frac{p}{1-p}\right)= \\
& =\beta_{0}+\beta_{1} v_{1}(r)+\beta_{2} v_{2}(r)+\ldots+\beta_{m} v_{m}(r)+\varepsilon,
\end{aligned}
$$

where $\beta_{0}, \beta_{1}, \ldots, \beta_{m}$ are the unknown parameters of the logistic regression, $v_{0}, v_{1}, \ldots, v_{m}$ are the independent variables in each terrain unit and $\varepsilon$ is the error associated with model 
Table 1. Aerial photographs used in this study. GSD is the ground sample distance (pixel size) after scanning the analogue images with a photogrammetric scanner.

\begin{tabular}{lrrr}
\hline Name & Date & Scale & GSD $(\mathrm{m})$ \\
\hline RAF & 1947 & $1: 30000$ & 0.60 \\
SPLAL & 1952 & $1: 18000$ & 0.41 \\
INAG & 2002 & $1: 8000$ & 0.18 \\
IGP & 2007 & $1: 46000$ digital & 0.50 \\
\hline
\end{tabular}

fitting. The logistic regression computations were performed using IBM SPSS Statistics v20, which performed the regression of the input data and returned the $\beta$ and $\varepsilon$ values. A model was built using the complete set of cliff instability predisposing factors and another model using the forward conditional approach. In the latter, after the regression computation, the factors (with all their variables) are added to the model, one by one, in decreasing order of relevance for model building, until a state is reached where the remaining factors are no longer relevant.

\section{Data acquisition and processing}

\subsection{Inventory of cliff failures}

Inventories of past cliff failures are a fundamental piece of information for application of statistically based methods. Aerial photograph-based cliff evolution monitoring and cliff failure inventory compilation, while usually less accurate and less convenient than other recent techniques (e.g. airborne LIDAR), especially when using old aerial surveys for which there are no camera calibration data, enables much longer monitoring periods, which may extend to the 1940s, to the older aerial photograph surveys available in many sea cliff dominated coastlines. These much wider monitoring periods are very convenient for getting a wider sampling window of the cliff retreat phenomena, which is highly irregularly spaced in space as in time, and in consequence enable much more representative samples of the cliff retreat events. It must be stressed that, in this study, the photogrammetric monitoring using archival aerial photography is only able to detect the larger cliff failures, which cause cliff top retreat larger than approximately 1.0 to $1.5 \mathrm{~m}$, with the smaller but much more frequent failures (Marques, 2008) remaining mostly undetected.

In this study, the cliff failure inventory was compiled using multi-temporal aerial digital photogrammetric methods, using aerial photographs of 1952, 2002 and 2007 (Table 1). Special techniques were used to enable the use of old aerial photographs without camera calibration data (Redweik et al., 2008, 2009). The photogrammetric techniques did not provide satisfactory results in the processing of the older aerial survey available dating from 1947, mainly because the photographs were taken with non-metric reconnaissance cameras. These photographs were used for photointerpretation comparison with the 1952 photographs for the identification of cliff failures that occurred between 1947 and 1952. The photogrammetric processing involved several aerotriangulation steps, generation of pseudo-camera data for the older aerial photographs without camera calibration information, stereo plotting of the cliff top, ridges and toe, and automatic generation of digital terrain models (Redweik et al., $2008,2009)$. The results were validated by systematic stereo photo interpretation, helped by oblique aerial photographs and field surveys.

This study enabled the detection and characterization of 137 cliff failures that occurred between 1947 and 2007 along the $15 \mathrm{~km}$-long cliffs. However, some of these failures occurred in stacks or correspond to block quarrying in low rocky parts of the coast which do not correspond to the sea cliffs. For this study, we only considered 119 cliff failures or groups of failures which occurred in the same place and could not be separated due to the wide time gap between aerial photograph surveys, which causes an inevitable degree of data amalgamation (Dong and Guzzetti, 2005). The cliff failures caused a net loss of $11195 \mathrm{~m}^{2}$ of planimetric area at the level of the cliffs top.

The distribution of failures and failure size along the cliff sections of the studied coast is quite variable, and is expressed by the cumulative number of failures and of planimetric area lost at the cliff top against the length of cliff top (Fig. 2). Using these plots and also considering the lithology of the cliffs, it is possible to separate 3 sub-sections with some degree of homogeneity of retreat behaviour. The slope of the linear regression of the selected plot sections expresses the average cliff retreat for the $60 \mathrm{yr}$ monitoring period, which divided by the number of years provides estimates of the mean cliff retreat. Computed mean retreat rates varied within one order of magnitude from $7 \times 10^{-3} \mathrm{~m} \mathrm{yr}^{-1}$ in lower Cretaceous strong sandstones and alternating marly limestones and marls to $3.8 \times 10^{-2} \mathrm{~m} \mathrm{yr}^{-1}$ in Miocene calcarenites with frequent karst sinkholes filled with Plio-Pleistocene silty sands (Fig. 2b). The dominant cliff failures in calcarenites and silty sands caused local cliff top retreat from $3 \mathrm{~m}$ to $16 \mathrm{~m}$, with a maximum recorded retreat of $26 \mathrm{~m}$, while in Cretaceous rocks the more frequent values varied between $1 \mathrm{~m}$ and $2.4 \mathrm{~m}$, with the larger values up to $9 \mathrm{~m}$ (Fig. 3). Most of the larger local retreat cliff failures occurred in Plio-Pleistocene silty sands and weak Miocene calcarenitedominated cliffs. Field evidence indicates that, with the exception of the larger failure recorded at the Praia do Canavial cliffs, the larger cliff top retreat values correspond to successions of failures occurred as a consequence of heavy rainfall frequently associated with sea storms, which increase the possibility of a near saturation of the toe of the slopes, but that could not be separated because of the large time periods separating the different aerial surveys used. 

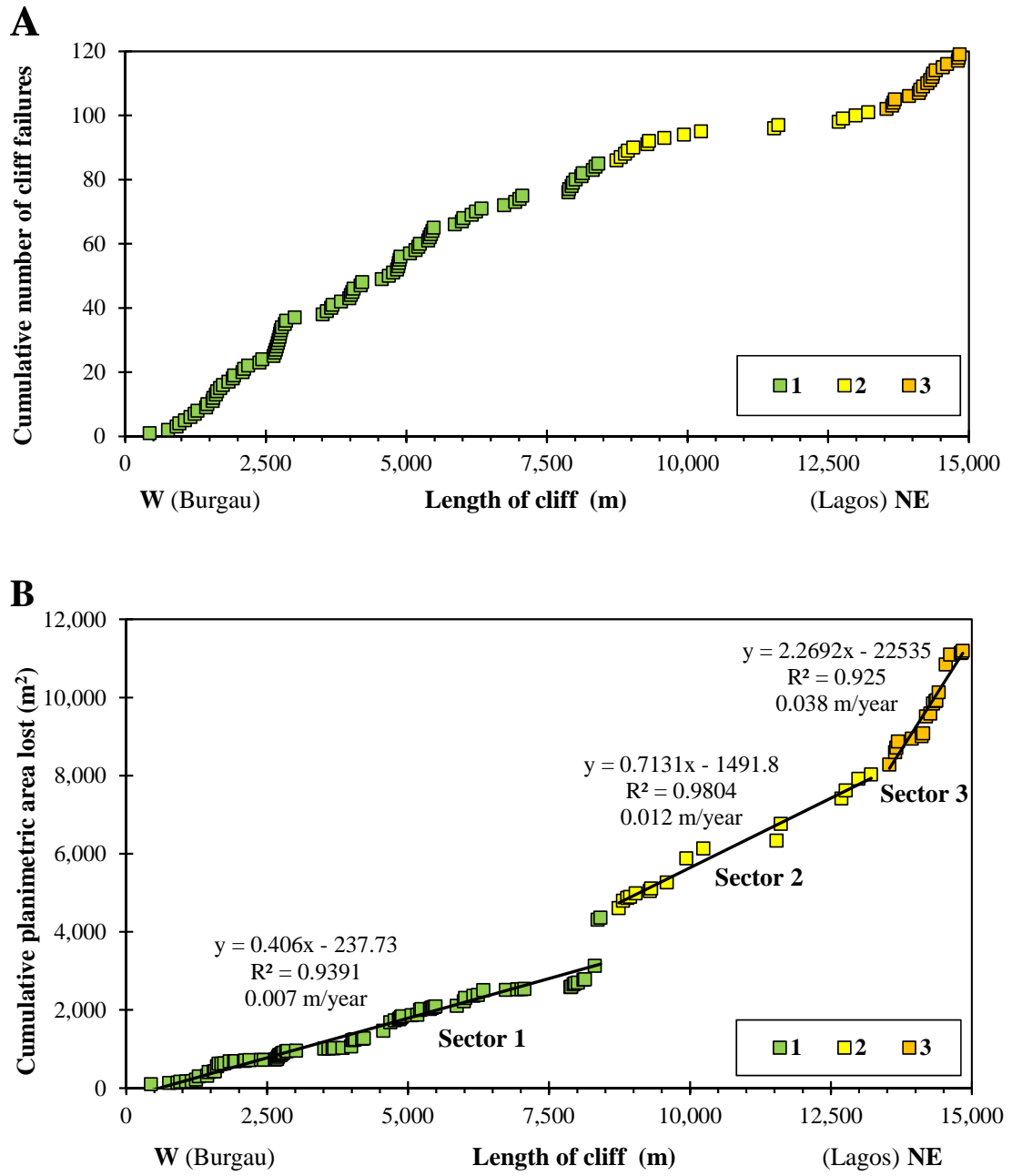

Fig. 2. Spatial distribution of cliff failures. (A) Cumulative number of cliff failures along the cliff lengths (from west to east). (B) Cumulative planimetric area lost at the level of the cliff tops, along the length of cliffs (sector extent in Fig. 1). The slope of the linear regressions corresponds to the mean retreat in metres for the $60 \mathrm{yr}$-long period of monitoring for each sector defined according to the frequency of cliff failures, planimetric area lost and geological units affected. Legend: 1 - Cliff failures in Cretaceous rocks; 2 - Cliff failures predominantly in Miocene calcarenites; 3 - Cliff failures predominantly in Plio-Pleistocene silty sands.

The cliff failures identified correspond to steeply sloping failure plane planar slides (58\%) mainly in Cretaceous alternating limestone and marls and sandstones, toppling failures (17\%) mainly in Miocene calcarenites, slumps (15\%) in Plio-Pleistocene silty sands, and the remaining $10 \%$ correspond to complex movements, rockfalls and undetermined cases. The failures correspond mainly to the mobilization of comparatively thin slabs of the cliff faces, with most of the larger cliff top retreat events corresponding to series of failures rather than unique failures. The only exception is the larger cliff planar slide, located at the Praia do Canavial cliffs, which caused the larger cliff top retreat of $26 \mathrm{~m}$ and the larger single horizontal area lost at the cliff top (Fig. 3): it was a failure mainly driven by an exceptional and local, several week-long water supply pipe rupture which caused severe water infiltration into the rock mass near the cliff top.
However, this slide occurred near to the place where a comparatively large cliff failure had already occurred a few years before and which was driven by natural causes. The plot of maximum local cliff top retreat against cliff height shows that all cliff failures caused cliff top retreat lower than cliff height, with most of the failures causing retreat much lower than cliff height (Fig. 4). Considering that the cliff failures cross section does not show strong variations in the inventory, a certain convergence of causes, mechanisms and triggering factors is assumed, giving support to an analysis which includes all data without failure type separation. The length of cliff top affected by failures varied within a large range (Fig. 5), from less than $4 \mathrm{~m}$ to approximately $100 \mathrm{~m}$, with the values lower than $30 \mathrm{~m}$ corresponding to circa $80 \%$ of the inventoried cases. 
A

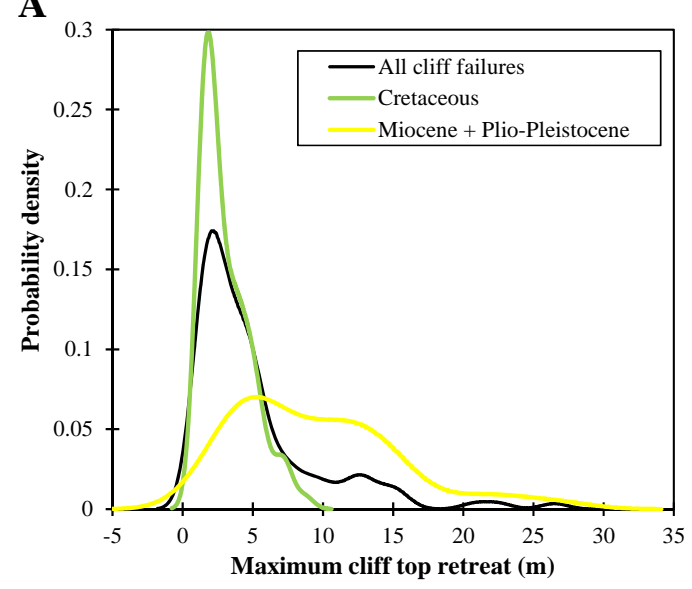

B

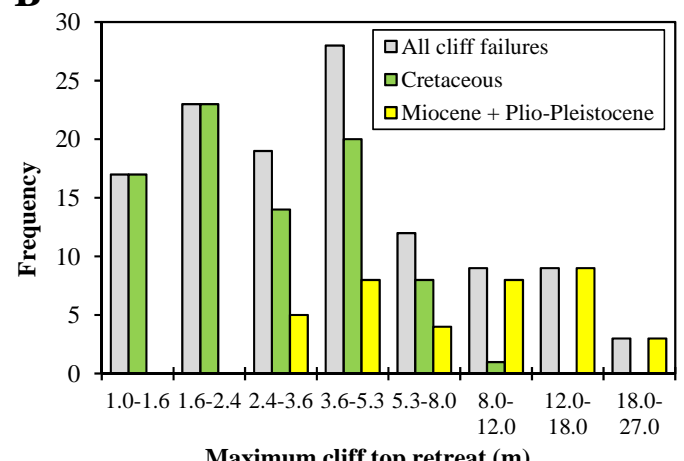

Fig. 3. (A) Probability density of maximum cliff top retreat, with probability densities computed with a kernel density estimation (Brunetti et al., 2009) using an MS EXCEL add-in (Ellison, 2002). (B) Histogram of maximum cliff top retreat caused by cliff failures in Cretaceous, and Miocene plus Plio-Pleistocene formations. Histogram class limits based on a $1.6 \times$ progression.

\subsection{Terrain units}

One important aspect of landslide hazard studies is the definition of the divisions of the study area in portions whose properties may be assumed as nearly constant in terms of the different cliff instability predisposing factors, i.e. the terrain units or domains to consider for application of the statistical methods. In the case of sea cliffs, a pixel-based approach, in spite of its convenience in use, is affected by several drawbacks, which include: some predisposing factor mapping (e.g. toe protection) cannot be extended to all unit cells that cover a given cliff face; the cliff stability is dependent on the predisposing factors present along the entire cliff face and not on a pixel per pixel basis; grid cells located landwards of the cliff top but with limits very close to it would produce low susceptibility values due to very small values of slope and other morphometrically derived factors, but this result would be misleading because its susceptibility is mainly

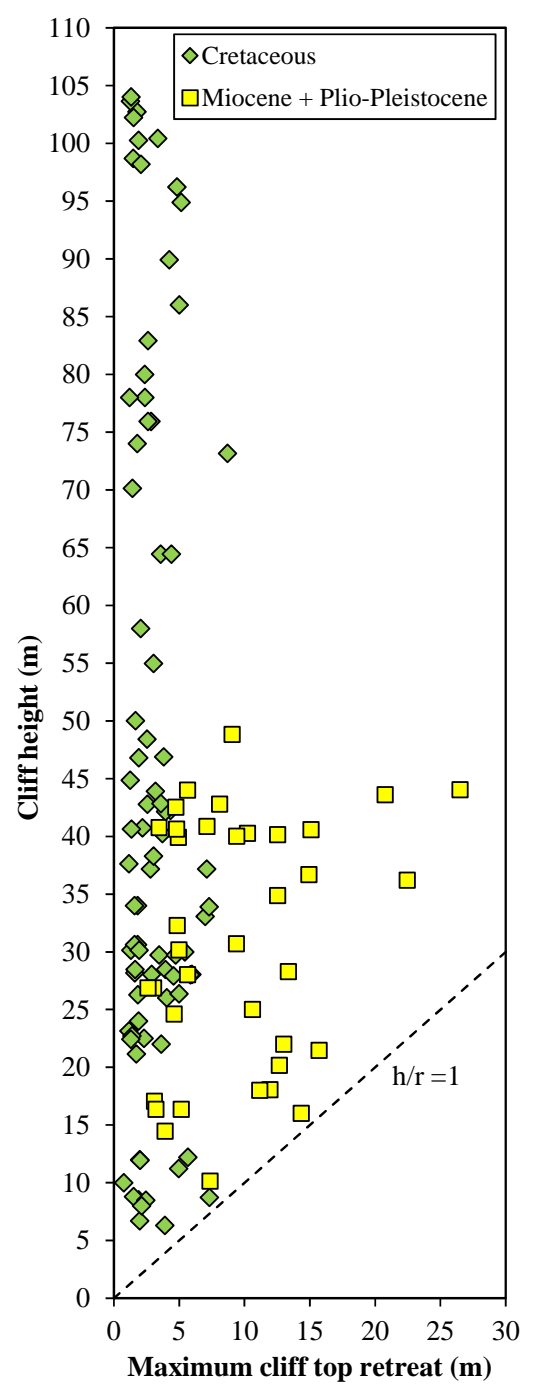

Fig. 4. Variation of maximum cliff top retreat caused by cliff failures in Cretaceous and Miocene plus Plio-Pleistocene formations against cliff height. Dashed line corresponds to cliff height to a maximum retreat ratio of 1 .

dependent on the adjacent cliff top cell values. Considering these problems, a terrain unit approach was selected.

Following a preliminary trial using $50 \mathrm{~m}$-long sections of the cliff top line, the mapping and analysis of the factors was made using terrain units defined along $25 \mathrm{~m}$-long sections of the cliff top line, smoothed with a $25 \mathrm{~m}$ radius of tolerance line. This size also corresponds to the limit of the majority of the values of the length of cliff top affected by retreat, and is a good balance between the detail of the mapping of the different predisposing factors and the number of resulting terrain units and their possible use for planning purposes.

At the ends of each $25 \mathrm{~m}$ smoothed cliff top line segment, the lateral limits of terrain units were drawn in directions approximately perpendicular to the cliff contour lines, thus crossing the manually digitized lines of the cliff top 

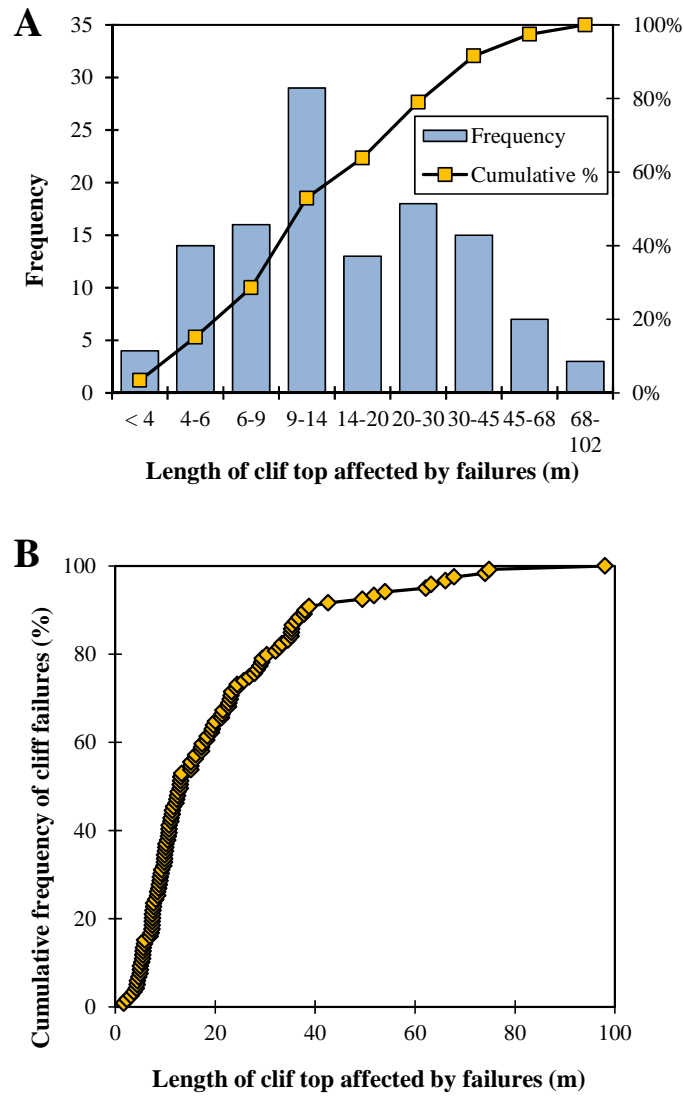

Fig. 5. Length of cliff top affected by sea cliff failures ordered by increasing order of values. (A) Histogram of cliff top length affected by cliff failures and corresponding cumulative frequency curve. Class limits based on a $1.5 \times$ progression. (B) Cumulative frequency plot of cliff top length affected by cliff failures.

and toe. This approach was slightly modified in the highly complex cliff plan contour of the eastern coastal section studied, which corresponds to the cliffs cut in the Miocene calcarenitic rocks and the Plio-Pleistocene overconsolidated silty sandy soils. In this coastal section, located eastwards of Praia do Canavial, the limits of the terrain units were manually adjusted to provide a better representation of cliff morphology, namely the aspect and plan curvature.

To enable a complete sampling of the morphometric properties of each terrain unit, $1 \mathrm{~m}$ buffers were created along the cliff top and toe lines, i.e. one half of the DTM grid cell used, and these buffer areas were added to the cliff terrain units. The study cliffs were then divided into 595 terrain units containing approximately $25 \mathrm{~m}$-long sections of the cliff top line, which corresponds to approximately $14875 \mathrm{~m}$ of the cliff top length.

\subsection{Sea cliff failure predisposing factors}

The predisposing factors considered were those that were susceptible to having a relation to cliff failure occurrence and which could be obtained with an acceptable level of work and detail compatible with a regional scale study. The geological and geomorphological factors were mapped at $1: 2000$ scale using existing geological maps, field surveys and vertical and oblique aerial photograph analysis, and included (Table 2):

a. Major lithological units including 16 classes (Fig. 6), where the lithological types are indicated by decreasing order of thickness, except when the lithological type is followed by the abbreviation for subordinate (sub). Superposition of the lithological types is also indicated when applicable.

b. Geological structure in terms of bedding dip relation with the cliff faces expressed in four classes: Horizontal (less than $10^{\circ}$ ) and against cliff face dipping (against slope); bedding dip direction outwards from the cliff face (i.e. nearly parallel to the cliff face dip), but dip lower than cliff face slope angle (inferior to slope); igneous rock masses with no visible structure (massive); bedding dip direction roughly parallel to the cliff face with dip higher than $10^{\circ}$ (parallel to slope).

c. Presence or absence of faults.

d. Presence and type of cliff toe protection against direct wave attack, including 18 classes (Fig. 6): plunging cliffs with no protection (No protection), cliff toe protection by debris accumulations of large cliff failures older than 1947 and not included in the inventory used in this study (talus deposits) and blocks fallen from the cliffs, mainly corresponding to already existing features in 1947 (blocks), sandy beach wide, sandy beach narrow, boulder beach (gravel beach), wave cut platforms (platform), large stacks (stacks), or various combination of these features (Table 2).

These geological and geomorphological factors were aggregated in the set of terrain units, considering all the features present in the basic mapping, except when these features were present in less than approximately $5 \%$ of the terrain unit area: in these cases the features are judged to be irrelevant in terms of cliff retreat behaviour, and in consequence were not considered for model construction. These processes caused the generation of a large number of variables, especially in toe protection and lithology factors, but this approach is the one that enables a closer representation of the base mapping produced and of the variability of the cliffs studied (Fig. 6).

The aspects related to cliff morphometry were derived from a 2 m grid DTM obtained from a 1:2000 aerophotogrammetric survey carried out by the national water authority (INAG), with source data (1:8000 scale aerial photographs) obtained between 2001 and 2003. The maps in vector format were the object of detailed and systematic checking and correction of errors in contour line elevation values, in order to enable the production of an accurate DTM. 


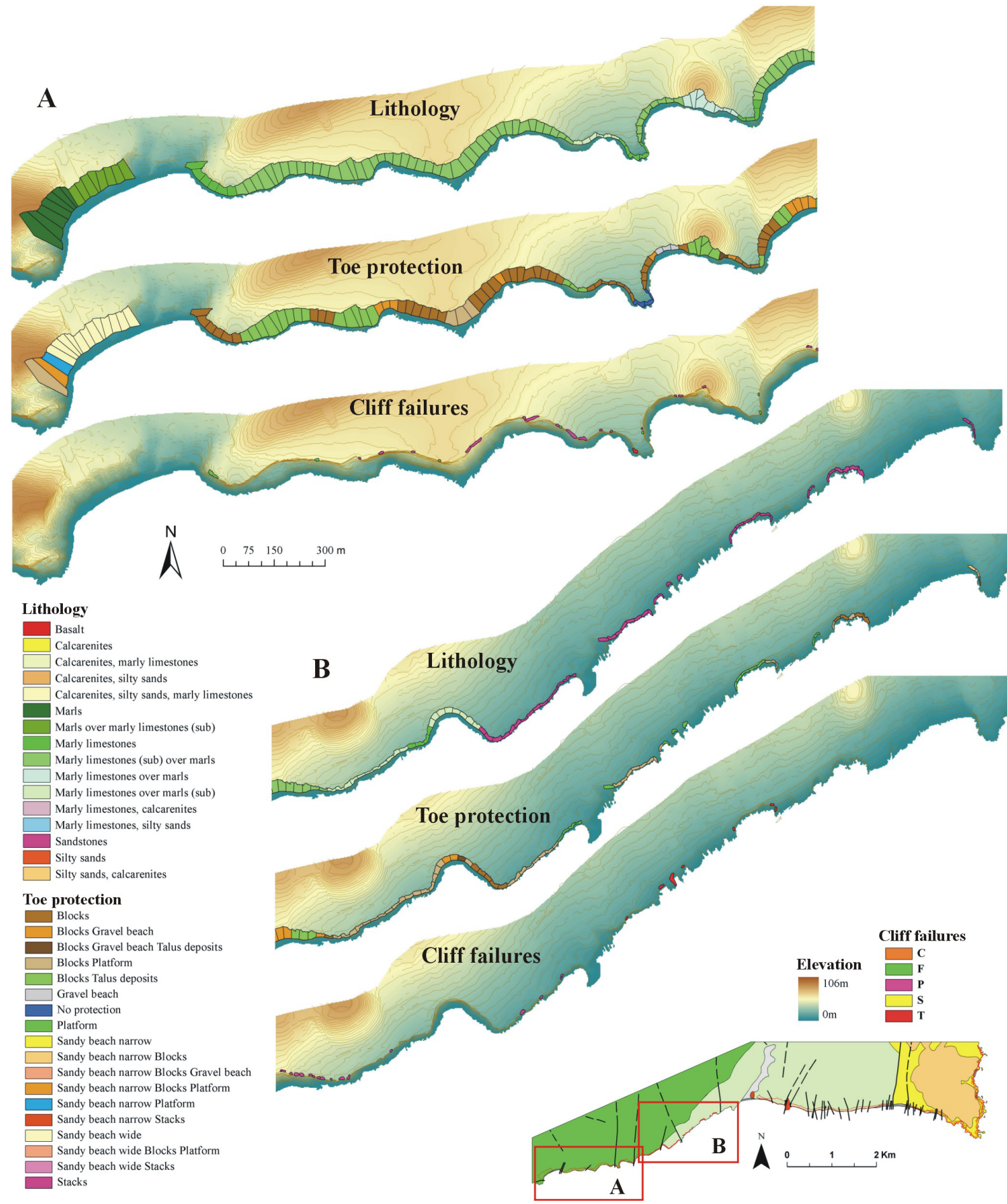

Fig. 6a. Lithology, toe protection and cliff failures in sections A and B. Lithology and toe protection mapped according to the terrain units used in this study. Cliff failure areas are not to scale to enable visualization. Cliff failures legend: C - Complex and not determined; $\mathrm{F}-$ Rockfalls; P - Planar failures; S - Slumps; T - Toppling failures. Contour line interval is $2 \mathrm{~m}$. 

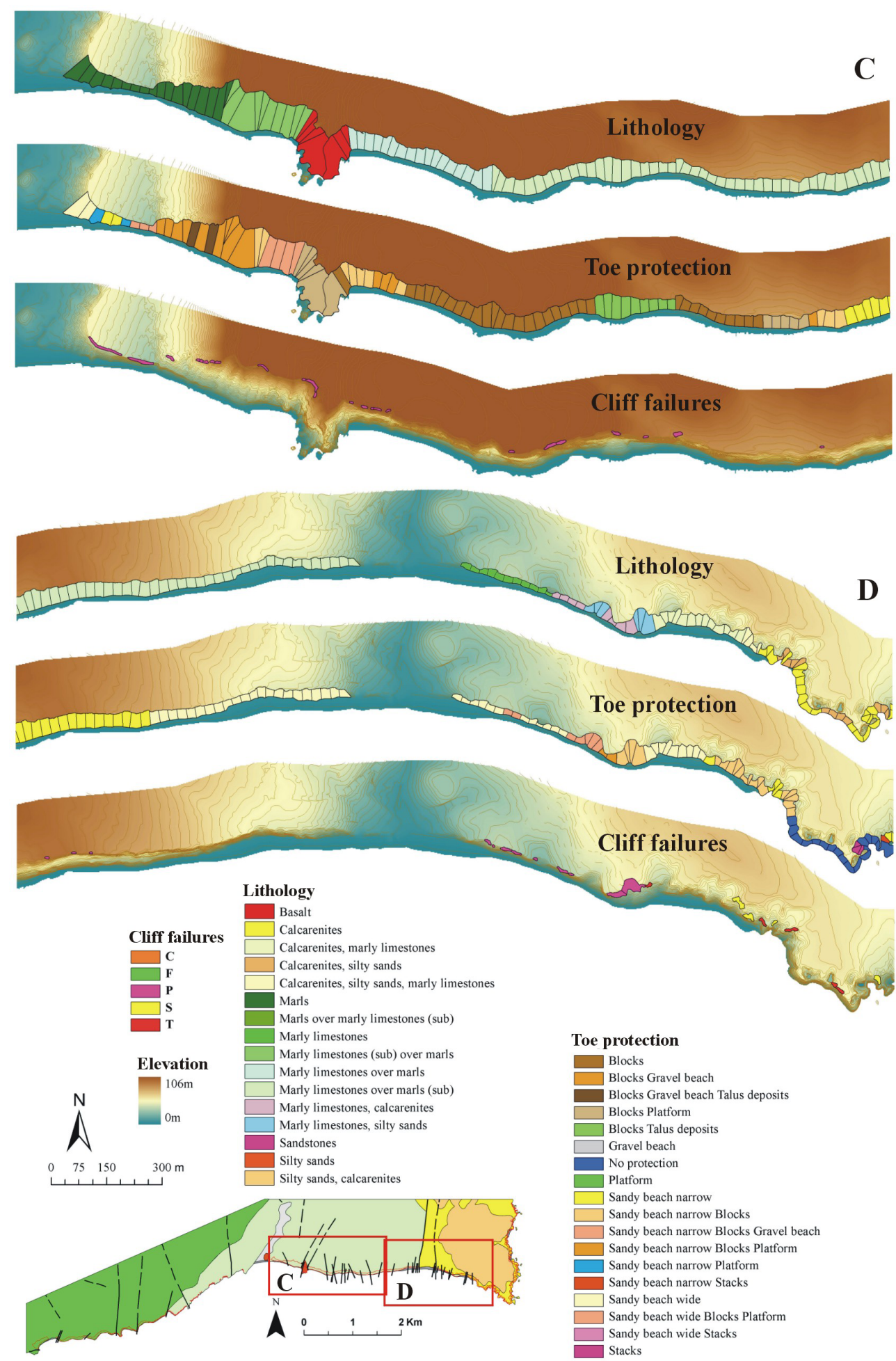

Fig. 6b. Lithology, toe protection and cliff failures in sections C and D. Lithology and toe protection mapped according to the terrain units used in this study. Cliff failure areas are not to scale to enable visualization. Cliff failures legend: $\mathrm{C}-\mathrm{Complex}$ and not determined; $\mathrm{F}-$ Rockfalls; P - Planar failures; S - Slumps; T - Toppling failures. Contour line interval is $2 \mathrm{~m}$. 


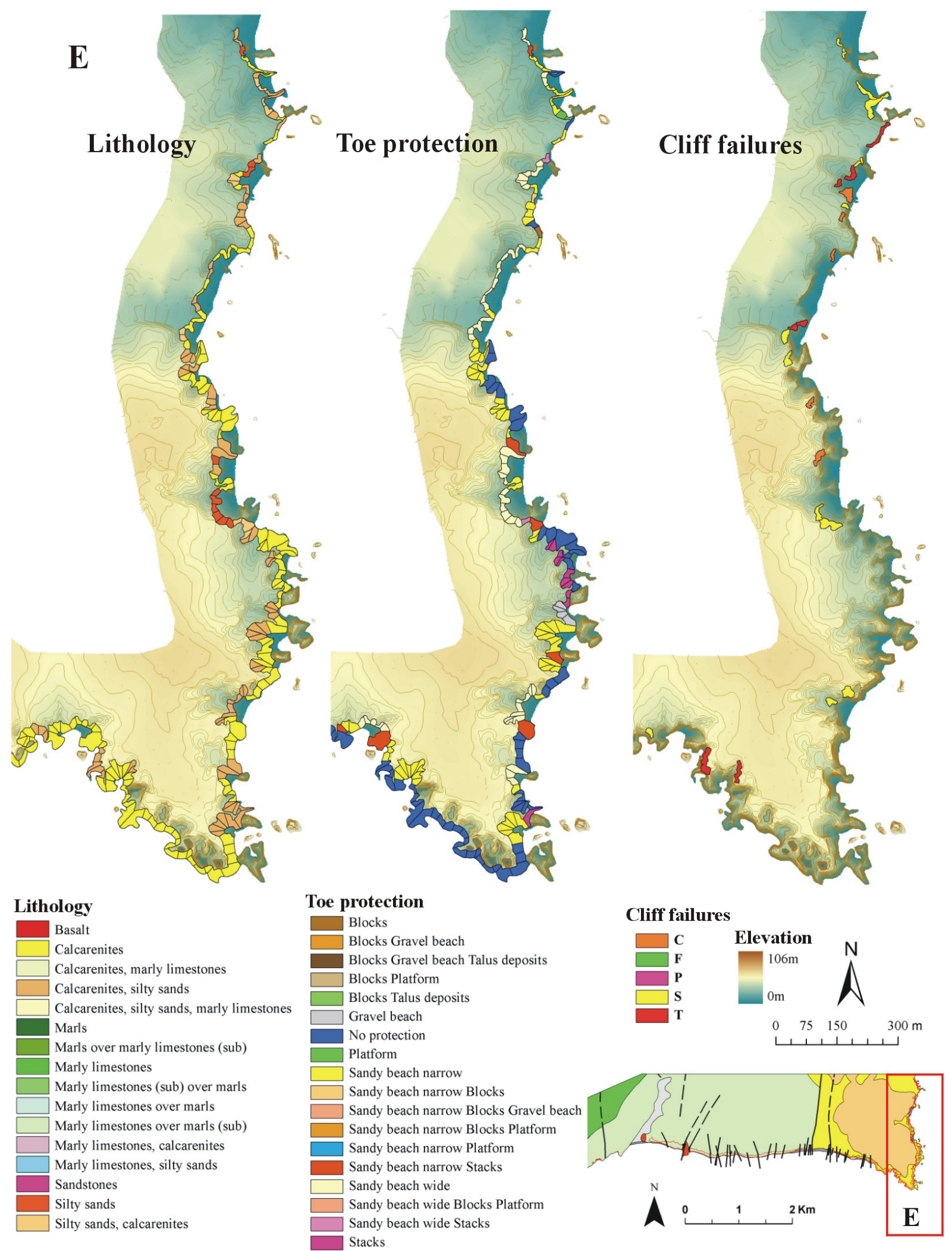

Fig. 6c. Lithology, toe protection and cliff failures in section E. Lithology and toe protection mapped according to the terrain units used in this study. Cliff failure areas are not to scale to enable visualization. Cliff failures legend: $\mathrm{C}-\mathrm{Complex}$ and not determined; $\mathrm{F}-\mathrm{Rockfalls;} \mathrm{P}$ - Planar failures; $\mathrm{S}$ - Slumps; T - Toppling failures. Contour line interval is $2 \mathrm{~m}$. 
Table 2. Information Value $\left(I_{i}\right)$ and Logistic Regression (Constant, $B$ values) results.

\begin{tabular}{|c|c|c|c|c|c|c|}
\hline \multirow{3}{*}{ Factors } & \multirow{3}{*}{ Variables } & \multirow{2}{*}{\multicolumn{3}{|c|}{$\begin{array}{l}\text { Information Value } \\
\qquad \begin{array}{c}(S=186 \\
N=595)\end{array}\end{array}$}} & \multicolumn{2}{|c|}{ Logistic Regression } \\
\hline & & & & & \multirow{2}{*}{$\begin{array}{c}\text { All } \\
\text { factors } \\
\beta\end{array}$} & \multirow{2}{*}{$\begin{array}{r}\text { Forward } \\
\text { stepwise } \\
\beta\end{array}$} \\
\hline & & $S_{i}$ & $N_{i}$ & $I_{i}$ & & \\
\hline \multirow{10}{*}{$\begin{array}{l}\text { Cliff } \\
\text { height }\end{array}$} & Logistic regression constant $\varepsilon$ & - & - & - & -21.0573 & -22.2740 \\
\hline & $6-17$ & 22 & 66 & 0.0642 & 1.2429 & 1.2681 \\
\hline & $17-24$ & 19 & 60 & 0.0129 & 0.4662 & 0.4334 \\
\hline & $24-30$ & 28 & 70 & 0.2465 & 0.6455 & 0.7020 \\
\hline & $30-34$ & 20 & 55 & 0.1512 & 0.5502 & 0.6083 \\
\hline & $34-39$ & 19 & 79 & -0.2622 & -1.2440 & -1.1980 \\
\hline & $39-42$ & 22 & 64 & 0.0950 & 0.1975 & 0.2325 \\
\hline & $42-46$ & 19 & 64 & -0.0516 & -0.8633 & -1.0266 \\
\hline & $46-74$ & 13 & 71 & -0.5349 & -1.7791 & -1.9397 \\
\hline & $74-106$ & 24 & 66 & 0.1512 & 0.0000 & 0.0000 \\
\hline \multirow{10}{*}{$\begin{array}{l}\text { Mean } \\
\text { slope }\end{array}$} & $28-35$ & 12 & 56 & -0.3776 & -2.2276 & -1.9344 \\
\hline & $35-39$ & 22 & 68 & 0.0343 & -1.4428 & -1.2071 \\
\hline & $39-41.5$ & 19 & 59 & 0.0297 & -1.9744 & -1.5568 \\
\hline & $41.5-43.5$ & 20 & 56 & 0.1332 & -1.4118 & -0.9103 \\
\hline & $43.5-46.5$ & 21 & 58 & 0.1469 & -0.7548 & -0.3732 \\
\hline & $46.5-49$ & 23 & 52 & 0.3471 & -0.0080 & 0.3215 \\
\hline & $49-51.5$ & 21 & 70 & -0.0412 & -0.7292 & -0.4878 \\
\hline & $51.5-54.5$ & 19 & 57 & 0.0642 & -0.1091 & 0.1147 \\
\hline & $54.5-58$ & 11 & 53 & -0.4096 & -0.0564 & 0.0617 \\
\hline & $58-67$ & 18 & 66 & -0.1365 & 0.0000 & 0.0000 \\
\hline \multirow[t]{8}{*}{ Aspect } & $\mathrm{N}$ & 3 & 16 & -0.5112 & -2.1334 & -2.3084 \\
\hline & $\mathrm{NE}$ & 8 & 38 & -0.3953 & -2.6951 & -2.7757 \\
\hline & $\mathrm{E}$ & 21 & 72 & -0.0693 & -1.5065 & -1.7546 \\
\hline & SE & 34 & 130 & -0.1784 & -0.8556 & -0.9341 \\
\hline & $\mathrm{S}$ & 80 & 240 & 0.0642 & -0.3098 & -0.4528 \\
\hline & SW & 30 & 75 & 0.2465 & -0.3461 & -0.4974 \\
\hline & $\mathrm{W}$ & 9 & 22 & 0.2690 & 0.0000 & 0.0000 \\
\hline & NW & 1 & 2 & 0.4697 & -20.6799 & -19.9799 \\
\hline \multirow{5}{*}{$\begin{array}{l}\text { Plan } \\
\text { curvature }\end{array}$} & Strongly concave & 21 & 45 & 0.4007 & 2.2219 & 2.0000 \\
\hline & Lightly concave & 23 & 77 & -0.0455 & 0.0184 & 0.0218 \\
\hline & Plan & 101 & 346 & -0.0685 & 0.1160 & 0.1031 \\
\hline & Lightly convex & 31 & 86 & 0.1425 & 0.7514 & 0.6961 \\
\hline & Strongly convex & 10 & 41 & -0.2482 & 0.0000 & 0.0000 \\
\hline \multirow[t]{16}{*}{ Lithology } & Basalt & 2 & 7 & -0.0899 & 0.3824 & 0.4676 \\
\hline & Calcarenites & 16 & 137 & -0.9846 & 1.0178 & 0.3180 \\
\hline & Calcarenites, marly limestones & 3 & 13 & -0.3035 & 0.9729 & 0.7889 \\
\hline & Calcarenites, silty sands & 35 & 84 & 0.2873 & 3.6573 & 2.8564 \\
\hline & Calcarenites, silty sands, marly limestones & 4 & 4 & 1.1628 & 23.1595 & 22.5443 \\
\hline & Marls & 15 & 25 & 0.6520 & 5.5645 & 5.3866 \\
\hline & Marls over marly limestones (sub) & $0 *$ & 8 & -0.9176 & -14.9728 & -16.3829 \\
\hline & Marly limestones & 13 & 30 & 0.3266 & 1.7924 & 2.1454 \\
\hline & Marly limestones (sub) over marls & 33 & 78 & 0.3026 & 4.4144 & 3.7155 \\
\hline & Marly limestones over marls & 6 & 25 & -0.2643 & 0.3523 & 0.5610 \\
\hline & Marly limestones over marls (sub) & 21 & 104 & -0.4371 & 0.8852 & 1.0269 \\
\hline & Marly limestones, calcarenites & 5 & 8 & 0.6928 & 2.9241 & 2.5536 \\
\hline & Marly limestones, silty sands & 3 & 6 & 0.4697 & 2.6485 & 2.3599 \\
\hline & Sandstones & 12 & 45 & -0.1589 & 0.0000 & 0.0000 \\
\hline & Silty sands & 9 & 10 & 1.0575 & 8.8960 & 7.5963 \\
\hline & Silty sands, calcarenites & 9 & 11 & 0.9621 & 6.7038 & 5.5824 \\
\hline
\end{tabular}


Table 2. Continued.

\begin{tabular}{|c|c|c|c|c|c|c|}
\hline \multirow{3}{*}{ Factors } & \multirow{3}{*}{ Variables } & \multirow{2}{*}{\multicolumn{3}{|c|}{$\begin{array}{l}\text { Information Value } \\
\qquad \begin{array}{c}(S=186 \\
N=595)\end{array}\end{array}$}} & \multicolumn{2}{|c|}{ Logistic Regression } \\
\hline & & & & & \multirow{2}{*}{$\begin{array}{c}\text { All } \\
\text { factors } \\
\beta\end{array}$} & \multirow{2}{*}{$\begin{array}{r}\text { Forward } \\
\text { stepwise } \\
\beta\end{array}$} \\
\hline & & $S_{i}$ & $N_{i}$ & $I_{i}$ & & \\
\hline \multirow{18}{*}{$\begin{array}{l}\text { Toe } \\
\text { protection }\end{array}$} & Blocks & 27 & 92 & -0.0631 & 20.3754 & 20.6081 \\
\hline & Blocks gravel beach & 9 & 23 & 0.2245 & 19.4296 & 19.6496 \\
\hline & Blocks gravel beach talus deposits & 2 & 4 & 0.4697 & 20.7828 & 20.8601 \\
\hline & Blocks platform & 15 & 53 & -0.0994 & 21.1748 & 21.6191 \\
\hline & Blocks talus deposits & 11 & 37 & -0.0502 & 20.6619 & 20.5737 \\
\hline & Gravel beach & 1 & 7 & -0.7831 & 17.3871 & 17.6927 \\
\hline & No protection & 11 & 80 & -0.8213 & 19.5409 & 19.6550 \\
\hline & Platform & 6 & 17 & 0.1214 & 21.4936 & 22.0698 \\
\hline & Sandy beach narrow & 31 & 94 & 0.0535 & 20.8057 & 20.9498 \\
\hline & Sandy beach narrow blocks & 21 & 32 & 0.7416 & 22.3400 & 22.4244 \\
\hline & Sandy beach narrow blocks gravel beach & 4 & 7 & 0.6032 & 18.0943 & 18.5671 \\
\hline & Sandy beach narrow blocks platform & 3 & 7 & 0.3155 & 20.9666 & 21.5188 \\
\hline & Sandy beach narrow platform & 2 & 3 & 0.7573 & 20.0850 & 20.1637 \\
\hline & Sandy beach narrow stacks & 1 & 7 & -0.7831 & 16.2115 & 16.9278 \\
\hline & Sandy beach wide & 37 & 109 & 0.0824 & 20.6562 & 20.6239 \\
\hline & Sandy beach wide blocks platform & 3 & 7 & 0.3155 & 19.5484 & 19.8746 \\
\hline & Sandy beach wide stacks & 2 & 2 & 1.1628 & 55.8467 & 54.6495 \\
\hline & Stacks & $0^{*}$ & 14 & -1.4863 & 0.0000 & 0.0000 \\
\hline \multirow{9}{*}{$\begin{array}{l}\text { Maximum } \\
\text { slope }\end{array}$} & $44-68$ & 18 & 55 & 0.0459 & -1.4738 & - \\
\hline & $68-72$ & 25 & 68 & 0.1622 & -0.3518 & - \\
\hline & $72-75$ & 26 & 60 & 0.3266 & -0.5477 & - \\
\hline & $75-77$ & 14 & 51 & -0.1300 & -0.8297 & - \\
\hline & $77-79$ & 24 & 85 & -0.1018 & -0.6844 & - \\
\hline & $79-81$ & 15 & 76 & -0.4599 & -1.3168 & - \\
\hline & $81-83$ & 17 & 67 & -0.2087 & -0.6287 & - \\
\hline & $83-85$ & 23 & 76 & -0.0324 & -1.0010 & - \\
\hline & $85-88$ & 24 & 57 & 0.2978 & 0.0000 & - \\
\hline \multirow[t]{2}{*}{ Faults } & No faults & 165 & 537 & -0.0172 & -0.3727 & - \\
\hline & Faults & 21 & 58 & 0.1469 & 0.0000 & - \\
\hline \multirow{4}{*}{$\begin{array}{l}\text { Bedding } \\
\text { dip }\end{array}$} & Horizontal, Against slope & 102 & 347 & -0.0615 & -0.6537 & - \\
\hline & Inferior to slope & 25 & 70 & 0.1332 & 0.6999 & - \\
\hline & Massive & 2 & 7 & -0.0899 & 0.0000 & - \\
\hline & Parallel to slope & 57 & 171 & 0.0642 & 0.0000 & - \\
\hline
\end{tabular}

* No cliff failures identified in the terrain units of the variable. For calculation the 0 was replaced by 0.999 to prevent an excessive increase in the resulting $I_{i}$ negative values.

The cliff top and toe lines which were the basis for the terrain units definition were manually digitized using the topography information (contour lines and slope) and orthophotomaps.

The topography used in this study was made after the occurrence of most cliff instabilities recorded in the inventory, implying that in many terrain units, the recorded values represent post-failure conditions and not pre-failure conditions. This has minor consequences for cliff height assessment, because, in most of the study area, the areas near the cliff top are mostly nearly horizontal or have low slope angles. On the contrary, cliff face angle assessment (maximum and mean slope) may be affected by this problem. In the cases of the cliff failures which caused the smaller values of cliff top retreat, the cross profile of the cliff did not suffer large variations of slope, and the same happened with the failures that mainly affected the sandy cliffs, which caused near-parallel retreat of the cliff face. In the larger failures, the morphometry of the cliff suffered changes which could not be considered in this study. However, this problem cannot be easily solved because the topographic survey used is the older one, which is accurate enough to carry this type of study (more accurate previous maps were only at $1: 25000$ scale).

The morphometric factors used obtained by processing of the $2 \mathrm{~m}$ grid cell DTM include: 
Table 3. Predisposing factors relevance based on $I_{i}$.

\begin{tabular}{lrr}
\hline & $\begin{array}{r}I_{i} \text { absolute } \\
\text { values mean }\end{array}$ & $\begin{array}{r}\text { Success rate } \\
\text { curve AUC }\end{array}$ \\
\hline Lithology & 0.5668 & 0.6935 \\
Toe protection & 0.4963 & 0.6415 \\
Aspect & 0.2754 & 0.6355 \\
Maximum slope & 0.1961 & 0.5650 \\
Plan curvature & 0.1811 & 0.6650 \\
Cliff height & 0.1744 & 0.5614 \\
Mean slope & 0.1720 & 0.5556 \\
Bedding dip & 0.0872 & 0.6667 \\
Faults & 0.0821 & 0.7885 \\
\hline
\end{tabular}

e. cliff height, which corresponds to the maximum elevation value in each terrain unit;

f. mean cliff slope angle which corresponds to the mean slope angle of all slope grid cells in each terrain unit;

g. maximum cliff slope angle recorded in each terrain unit.

For aspect and curvature assessment, the information derived from a $2 \mathrm{~m}$ DTM reflected very small local variations which were not representative of the global terrain conditions in each terrain unit. After several trials with DTMs with grid cells of 2, 4, 6 and $10 \mathrm{~m}$, the $6 \mathrm{~m}$ grid cell DTM was retained for the computing of aspect and plan curvature, since it provided an adequate balance of detail and smoothing of small local sharp variations in the topography, which did not reflect the general character of each terrain unit. The several attempts made to obtain reasonable results for the profile curvature from the DTMs were unsuccessful, and in consequence this factor was not considered in this study.

The $6 \mathrm{~m}$ grid cell DTM-derived factors were:

h. aspect (direction of cliff face exposure), which corresponds to the mean direction of exposure of the cliffs that bears some relation to the perceived intensity of the wave regime in the different parts of the study area;

i. mean plan curvature of the cliff faces obtained by classification of the computed plan curvatures in each terrain unit in four classes separated by curvature values of $-3.0,-0.5,0.5$, and 3.0 , in order to avoid the heavy influence of cells with very low (negative) or high curvatures which would otherwise have an excessive influence on the mean values computed for each cell. The mean values of the reclassified plan curvature values were retained and expressed in a qualitative scale which includes 5 terms: strongly concave; slightly concave; plan; slightly convex; strongly convex. The results were the object of systematic checking to detect possible errors of aspect and curvature assessment.
Considering that the shape of most cliff failures corresponds to the detachment of relatively thin and high slabs of rocks or soils, separated by steeply dipping failure surfaces of planar, slump or toppling failures, the analysis of the inventory data was made including all events recorded, and the dependent variable level is composed of terrain units with cliff failures (186) in a total number of 595 terrain units.

In the categorical factor processing (lithology, bedding dip, toe protection, faults) were retained the classes which were mapped along the study area. The numerical factor aspect was classified according to the 8 general geographic directions and the plan curvature in 5 classes (strongly concave; slightly concave; plan; slightly convex; strongly convex). The classification of the numerical predisposing factors cliff height, maximum slope and mean slope in classes followed a near quantile approach in order to enable a near homogeneous distribution of terrain units in each variable of each factor (Table 2). This approach was preferred to a classification based on the entire pixel data included in the area defined by all the terrain units, because this would lead to lower and higher value classes which would contain few or even no cases, and in consequence would not be useful for the model construction.

\section{Results, validation and discussion}

The classification of factors in variables (Table 2) provided two variables with zero cliff instabilities: "Marls over marly limestones (sub)" of factor "Lithology" and "Stacks" of factor "Toe protection". These variables are meaningful in the context of the studied coast and to enable the $I_{i}$ computation; an artificial value of 0.999 for cliff failures was considered instead of a value near zero, in order to prevent an excessive increase in the resulting $I_{i}$ negative values.

The forward stepwise conditional logistic regression analysis indicated that the relevant factors for model construction were, from step 1 to step 6, "Lithology", "Toe protection", "Cliff height", "Mean slope", "Plan curvature" and "Aspect" ( $\beta$ and $\varepsilon$ values in Table 2 ). This is somewhat supported by a global analysis of the larger positive or negative $I_{i}$ values, which mainly correspond to variables of the factors "Toe protection" and "Lithology", with minor contributions of variables of factors "Aspect", "Cliff height", "Mean slope" and "Maximum slope". The relative importance of each factor was tentatively analysed by computing the success rate area under the curve (AUC) for each of the factors analysed separately, and also by comparing the mean of the absolute values of $I_{i}$ for each factor (Table 3), with the latter providing results closer to those yielded by the logistic regression.

The success rate curves of the models produced with the logistic regression of all factors and forward conditional with 6 factors, and the information value with all factors enabled the computation of the corresponding AUCs (Table 4). The AUCs obtained suggest that the success rate results are 
Table 4. Success rate and ROC curves area under the curve (AUC) for the different models.

\begin{tabular}{lrr}
\hline Model & $\begin{array}{r}\text { AUC } \\
\text { (success rate) }\end{array}$ & $\begin{array}{r}\text { AUC } \\
\text { (ROC) }\end{array}$ \\
\hline Ideal model for this situation & 0.8437 & 1.000 \\
Logistic regression with all factors & 0.7509 & 0.8638 \\
Logistic regression FwCond: Lithology, ToeProt, Height, Mean slope, Plancurv, Aspect & 0.7425 & 0.8516 \\
$I_{i}$ model with all factors & 0.7017 & 0.7922 \\
$I_{i}$ : Lith, ToeProt, Aspect, MaxSlope, PlanCurv, Height, MeanSlope, BedDip & 0.7021 & - \\
$I_{i}:$ Lith, ToeProt, Aspect, MaxSlope, PlanCurv, Height, MeanSlope & 0.7029 & - \\
$I_{i}$ : Lith, ToeProt, Aspect, MaxSlope, PlanCurv, Height & 0.6989 & - \\
$I_{i}$ : Lith, ToeProt, Aspect, MaxSlope, PlanCurv & 0.6859 & - \\
$I_{i}$ : Lith, ToeProt, Aspect, MaxSlope & 0.6805 & - \\
$I_{i}:$ Lith, ToeProt, Aspect & 0.6734 & - \\
$I_{i}$ : Lith, ToeProt & 0.6667 & - \\
$I_{i}$ : Lith & 0.6583 & - \\
\hline
\end{tabular}

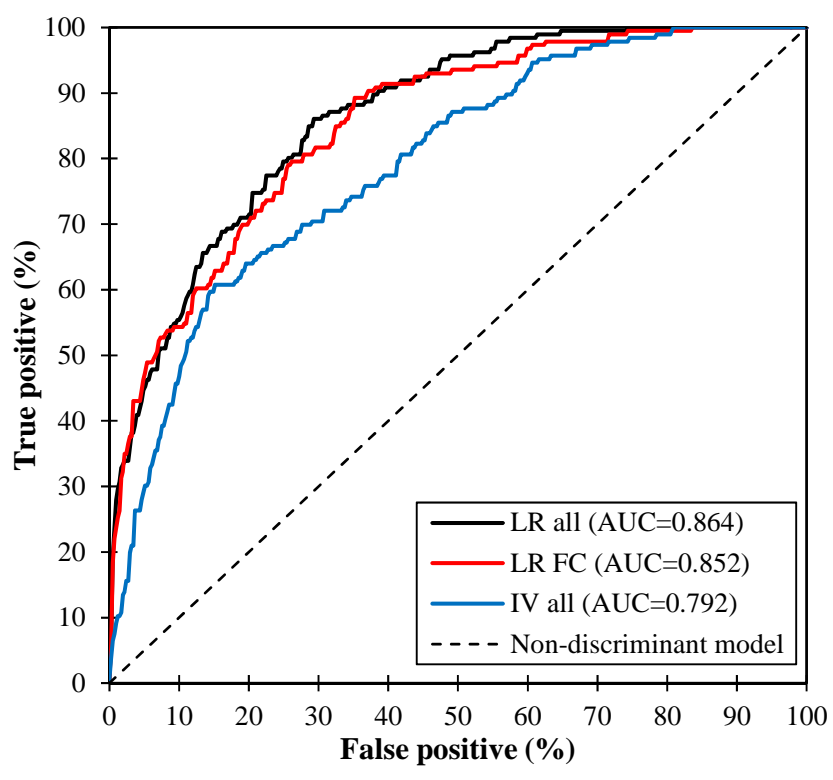

Fig. 7. Receiver operating characteristic (ROC) curves of the models produced in this study with the corresponding areas under the curves (AUC). Legend: LR all - Logistic regression with all factors; LR FC - Logistic regression forward conditional; IV all - Information value with all factors.

acceptable, because in this study area there is a large proportion of terrain units with cliff failures (186 out of 595, $31.3 \%$ ). In fact, the "ideal model" for this situation, one that could predict only terrain units with cliff failures in the higher susceptibility values, would only provide an AUC value of 0.844 , making the results of the model much more meaningful. A different perspective of the results is obtained using the false positive against the true positive curves and corresponding AUCs (Table 4, Fig. 7), as in this type of curve the "ideal model" corresponds to AUC $=1$.
As expected, the logistic regression provided significantly better results than the information value, with this simple method being only useful for enabling a direct evaluation of the relative contribution of the factors for the models and of the adequacy of the classification of factors in variables. In Figs. 8 and 9 are the maps of the results obtained with the best model in this study, the logistic regression with all factors, with the indication of the terrain units with cliff failures, to enable a visual confirmation of the adequacy of the model.

Lithology is one of the most important factors, mainly because it reflects the cliff rock mass strength, together with toe protection, which plays a major role in controlling wave erosion and attack at the cliff toe. Aspect is probably the third factor in terms of relevance, because it partially reflects the main characteristics of the intensity of the wave action on this particular coastline. The remaining factors (mean slope, height and plan curvature) played a minor role, but nevertheless contributed to the increase in the success rates of the computed models.

Mean slope, faults and bedding dip were discarded by the forward conditional logistic regression, indicating that these factors are not relevant for model construction under the particular circumstances of the studied area. This is partially confirmed by analysis of $I_{i}$ models, which indicate that models that do not include faults and bedding dip have a slightly better performance.

The relative importance of the different factors considered in this study is probably conditioned to an uncertain degree by the specific geological and geomorphological context of the cliffs and coastline analysed. Studies carried out on other types of cliffs may produce different results, and in consequence it seems advisable to test the models performance with all factors before discarding the least relevant for describing the cliff failure processes.

The models produced in this study show good agreement with the inventories that were used to build them, and in consequence, the validation stage corresponds to success rates. The predictive capacity of the models was not analysed due 


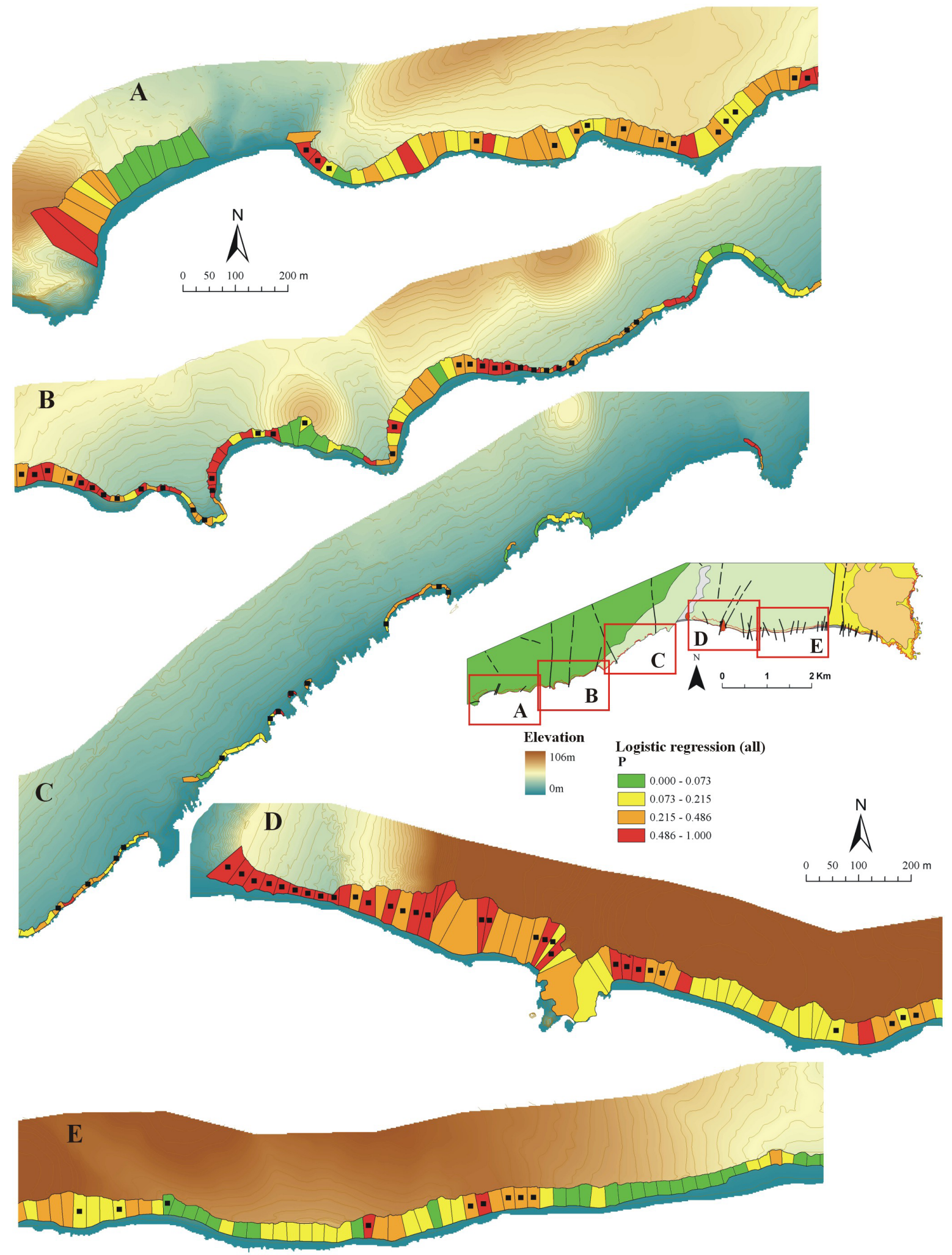

Fig. 8. Susceptibility mapping (1/2) based on the logistic regression model with all factors, with indication (dot) of the terrain units with cliff failures, for the cliff sections A, B, C, D and E, with general legend and localization map. Classification of logistic regression probability values in quantile-based classes. Contour line interval is $2 \mathrm{~m}$. 

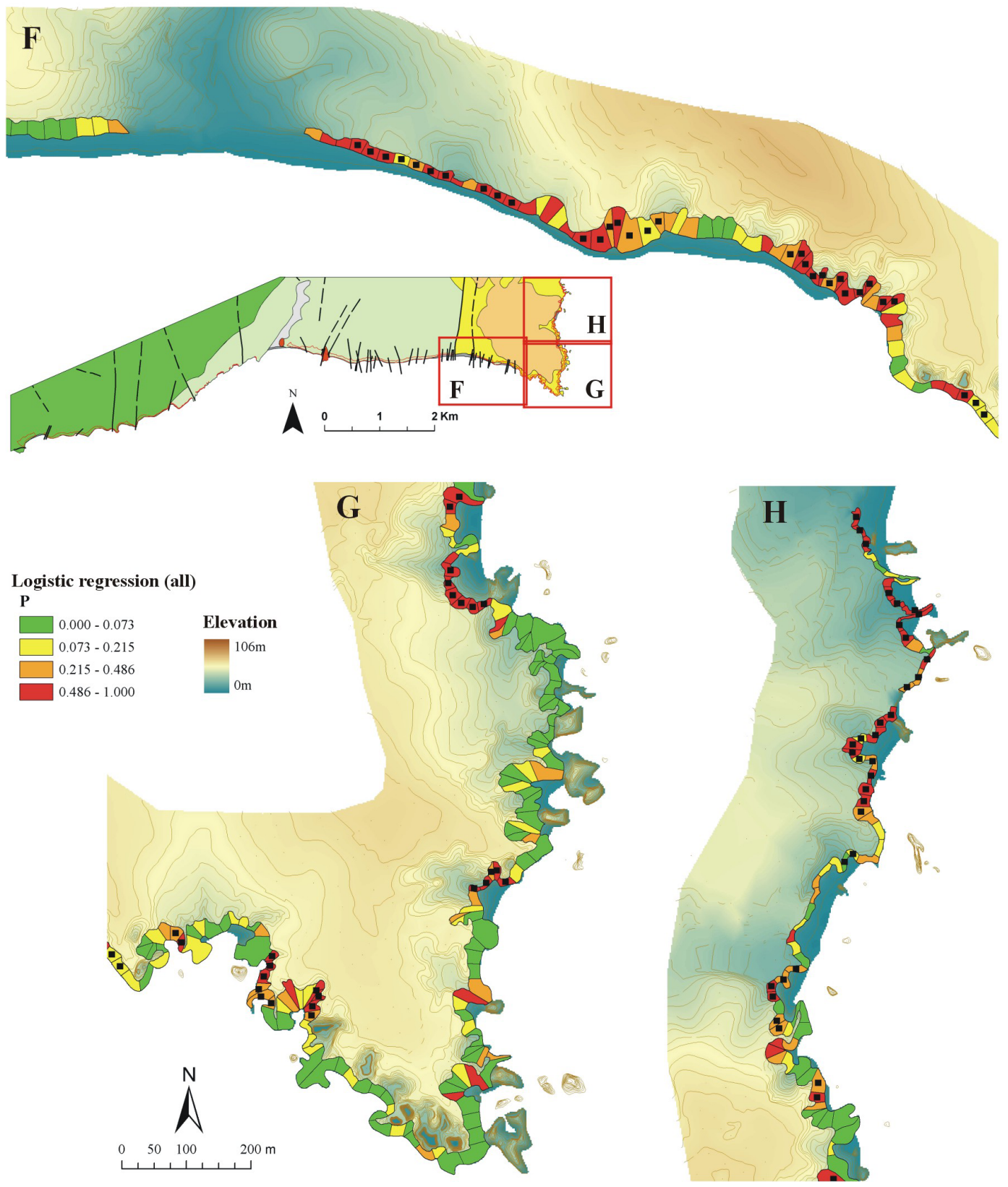

Fig. 9. Susceptibility mapping (2/2) based on the logistic regression model with all factors, with indication (dot) of the terrain units with cliff failures, for the cliff sections F, G and $\mathrm{H}$ with general legend and localization map. Classification of logistic regression probability values in quantile based classes. Contour line interval is $2 \mathrm{~m}$.

to limitations of the inventory, which was compiled with very wide and extremely different time periods between the aerial photographs used. In fact, the 2002 to 2007 last monitoring period was atypical of the general evolution of the cliffs, and only provided 4 small cliff failures. The model construction with the 1947 to 2002 inventory produced results close to the global models presented, but the 2002 to 2007 inventory data was clearly not sufficient to enable a meaningful model predictive capacity assessment.

\section{Conclusions}

The statistical methods used in this study, the information value and especially the logistic regression, provided models which enable an objective assessment of the relations between a set of predisposing factors related to the geology and geomorphology of the cliffs, and the occurrence of failures which cause cliff top retreat. The models performance was assessed with success rate and ROC curves, with results indicating that the models and the proposed approaches are 
adequate for describing the location of cliff failure inventory data for the $60 \mathrm{yr}$ monitoring period.

With few exceptions, the predisposing factors of sea cliff failure used in this study contributed to the models performance. Lithology is always the most relevant factor, suggesting that the efforts put into detailed lithological mapping are the most beneficial for the susceptibility models quality. There are no indications that the other factors' contribution to the models follows a general rule, but it is probably related to the specific context of the sea cliffs studied. As the effort put into mapping the predisposing factors is not disproportionate, especially the morphometric data which is easily obtained in the GIS environment, it seems advisable that in studies carried out on other cliffs, all of the proposed factors should be considered. Information on wave action was not available with the required degree of quality, and was not considered in this study, but may easily be added when available.

The terrain units based on uniform length segments of cliff top line were effective, with the $25 \mathrm{~m}$-long segments providing better results than larger ones, although there is much room for testing other terrain unit sizes and definition approaches.

Due to inventory data limitations, the predictive capacity of the models could not be tested. However, the results obtained in this study suggest that the methods used may have a good potential for the assessment of the susceptibility of sea cliff failures for planning purposes, which is, in consequence, a step towards objective sea cliff hazard assessment.

Acknowledgements. Acknowledgements are due to CCDR Algarve for funding, to the former Instituto Geográfico Português (IGP) for making some aerial surveys available under the FIGIEE programme, and also to Rani Calvo and another anonymous reviewer for critical revisions and suggestions, which enabled the improvement of the manuscript.

Edited by: A. Günther

Reviewed by: R. Calvo and one anonymous referee

\section{References}

Bird, E. (Ed.): Coastal geomorphology: an introduction, John Wiley and Sons, Chichester, 2000

Bromhead, E. and Ibsen, M.-L.: A review of landsliding and coastal erosion damage to historic fortifications in South East England, Landslides, 3, 341-347, 2006.

Brunetti, M. T., Guzzetti, F., and Rossi, M.: Probability distributions of landslide volumes, Nonlin. Processes Geophys., 16, 179-188, doi:10.5194/npg-16-179-2009, 2009.

Carrasco, A. R., Ferreira, Ó., Matias, A., and Dias, J. A.: Historic monuments threatened by coastal hazards at Boca do Rio, Algarve, Portugal, Coast. Manage. 35, 163-179, 2007.

Castedo, R., Fernández, M., Trenhaile, A. S., and Paredes, C.: Modeling cyclic recession of cohesive clay coasts: Effects of wave erosion and bluff stability, Mar. Geol., 335, 162-176, 2013.
Cox, D. R.: The regression analysis of binary sequences (with Discussion), J. R. Statist. Soc., B, 20, 215-242, 1958.

De Pippo, T., Donadio, C., Pennetta, M., Petrosino, C., Terlizzi, F., and Valente, A.: Coastal hazard assessment and mapping in Northern Campania, Italy, Geomorphology, 97, 451-466, 2008.

Del Río, L. and Gracia, F. J.: Erosion risk assessment of active coastal cliffs in temperate environments, Geomorphology, 112, 82-95, 2008.

Dewez, T. J. B., Rohmer, J., Regard, V., and Cnudde, C.: Probabilistic coastal cliff collapse hazard from repeated terrestrial laser surveys: case study from Mesnil Val (Normandy, northern France), J. Coast. Res., SI 65, 702-707, 2013.

Dong, P. and Guzzetti, F.: Frequency-size statistics of coastal softcliff erosion, ASCE, Journal of Waterways, Port, Coast. Ocean Eng., 131, 37-42, 2005.

Dornbusch, U., Robinson, D. A., Moses, C. A., and Williams, R. B. G.: Temporal and spatial variations of chalk cliff retreat in East Sussex, 1873 to 2001, Mar. Geol., 249, 271-282, 2008.

Ellison, S.: Kernel density estimation based on Royal Society of Chemistry Analytical Methods Committee, Technical brief No. 4, available at: http://www.rsc.org/Membership/Networking/ InterestGroups/Analytical/AMC/Software/kerneldensities.asp (last access: 23 October 2013), 2002.

Emery, K. O. and Kuhn, G. G.: Sea cliffs: Their processes, profiles and classification, Geol. Soc. Am. Bull., 93, 644-654, 1982.

Fall, M., Azzam, R., and Noubactep, C.: A multi-method approach to study the stability of natural slopes and landslide susceptibility mapping, Eng. Geol., 82, 241-263, 2006.

Günther, A. and Thiel, C.: Combined rock slope stability and shallow landslide susceptibility assessment of the Jasmund cliff area (Rügen Island, Germany), Nat. Hazards Earth Syst. Sci., 9, 687698, doi:10.5194/nhess-9-687-2009, 2009.

Guzzetti, F., Reichenbach, P., Cardinali, M., Galli, M., and Ardizzone, F.: Probabilistic landslide hazard assessment at the basin scale, Geomorphology, 72, 272-299, 2005.

Hall, J. W., Meadowcroft, I. C., Lee, E. M., and van Gelder, P. H. A. J. M.: Stochastic simulation of episodic soft coastal cliff recession, Coast. Eng., 46, 159-174, 2002.

Hapke, C. and Plant, N.: Predicting coastal cliff erosion using a Bayesian probabilistic model, Mar. Geol., 278, 140-149, 2010.

Hosmer, D. and Lemeshow, S.: Applied Logistic Regression, New York, Wiley, 2000.

Katz, O. and Mushkin, A.: Characteristics of sea-cliff erosion induced by a strong winter storm in the eastern Mediterranean, Quaternary Res., 80, 20-32, 2013.

Lee, E. M., Hall, J. W., and Meadowcroft, I. C.: Coastal cliff recession: The use of probabilistic prediction methods, Geomorphology, 40, 253-269, 2001.

Lee, E. M., Meadowcroft, I. C., Hall, J. W., and Walkden, M.: Coastal landslide activity: a probabilistic simulation model, B. Eng. Geol. Environ., 61, 347-355, 2002.

Marques, F. M. S. F.: The sea cliffs of the coast of Algarve, Dynamics, processes and mechanisms, University of Lisbon, Ph.D. thesis, 556 pp., 1997.

Marques, F. M. S. F.: A simple method for the measurement of cliff retreat from aerial photographs, Zeitschrift für Geomorphologie - Supplementbände, 144, 39-59, 2006. 
Marques, F. M. S. F.: Magnitude-frequency of sea cliff instabilities, Nat. Hazards Earth Syst. Sci., 8, 1161-1171, doi:10.5194/nhess8-1161-2008, 2008.

Marques, F. M. S. F. and Andrade, C.: Parecer sobre risco associado às arribas do Algarve. Fac. Sciences Univ. Lisbon report to Administração da Região Hidrográfica do Algarve, Faro, Portugal, 25 pp., 2009 (in Portuguese).

Milheiro-Oliveira, P.: Bayesian statistical methods for modeling and prediction of major landslides in coastal areas, Coastal Eng. J., 49, 45-61, 2007.

Moore, L. J. and Griggs, G. B.: Long-term cliff retreat and erosion hotspots along the central shores of the Monterey Bay National Marine Sanctuary, Mar. Geol., 181, 265-283, 2002.

Naylor, L. A., Stephenson, W. J., and Trenhaile, A. S.: Rock coast geomorphology: Recent advances and future research directions, Geomorphology, 114, 3-11, 2010.

Nunes, M., Ferreira, Ó, Schaefer, M., Clifton, J., Baily, B., Moura, D., and Loureiro, C.: Hazard assessment in rock cliffs at Central Algarve (Portugal): A tool for coastal management, Ocean Coast. Manage., 52, 506-515, 2009.

Redweik, P., Marques, F., and Matildes, R.: A strategy for detection and measurement of the cliff retreat in the coast of Algarve (Portugal) by photogrammetry, EARSeL eProceedings, 7, 92-104, 2008.

Redweik, P., Matildes, R., Marques, F. M. S. F., and Santos, L.: Photogrammetric methods for monitoring cliffs with low retreat rate, J. Coast. Res., SI 56, 1577-1581, 2009.

Rocha, R. B., Ramalho, M. M., Antunes, M. T., and Coelho, A. V. P.: Carta Geológica de Portugal na escala 1: 50000 e Notícia Explicativa da Folha 52-A, Portimão, Serviços Geológicos de Portugal, Lisboa, 1983 (in Portuguese).

Rosser, N., Lim, M., Petley, D., Dunning, S., and Allison, R.: Patterns of precursory rockfall prior to slope failure, J. Geophys. Res., 112, F04014, doi:10.1029/2006JF000642, 2007.
Soeters, R. and Van Westen, C. J.: Slope instability recognition, analysis and zonation, in: Landslides. Investigation and Mitigation, edited by: Turner, A. K. and Schuster, R. L., Transportation Research Board, Special Report 247, National Academy Press, Washington DC, 129-177, 1996.

Sunamura, T.: Geomorphology of Rocky Coasts, Wiley, New York, 302 pp., 1992.

Teixeira, S. B.: Geodinâmica, ocupação e risco na Praia María Luísa (Albufeira), Administração da Região Hidrográfica do Algarve Report, Faro, Portugal, 24 pp., 2009 (in Portuguese).

Trenhaile, A. S.: Geomorphology of Rock Coasts, Clarendon Press, Oxford, 384 pp., 1987.

Varnes, D. J.: Landslide Hazard Zonation: A Review of Principles and Practice, UNESCO Press, Paris, 63 pp., 1984.

Yin, K. L. and Yan, T. Z.: Statistical prediction models for slope instability of metamorphosed rocks, in: Landslides, Proceedings of the Fifth International Symposium on Landslides, edited by: Bonnard, C., Lausanne, Switzerland, Balkema, Rotterdam, 2, 1269-1272, 1988.

Young, A. P., Flick, R. E., Gutierrez, R., and Guza, R. T.: Comparison of short-term sea cliff retreat measurement methods in Del Mar, California, Geomorphology, 112, 318-323, 2009.

Young, A. P., Guza, R. T., O'Reilly, W. C., Flick, R. E., and Gutierrez, R.: Short-term retreat statistics of a slowly eroding coastal cliff, Nat. Hazards Earth Syst. Sci., 11, 205-217, doi:10.5194/nhess-11-205-2011, 2011.

Walkden, M. J. A. and Hall, J. W.: A predictive Mesoscale model of the erosion and profile development of soft rock shores, Coastal Eng., 52, 535-563, 2005.

Wu, Y., Yin, K., and Liu, Y.: Information analysis system for landslide hazard zonation, in: Landslides in Research, Theory and Practice, edited by: Bromhead, E., Dixon, N., and Ibsen, M.-L., 3, Thomas Telford, London, 1593-1598, 2000.

Zêzere, J. L.: Landslide susceptibility assessment considering landslide typology. A case study in the area north of Lisbon (Portugal), Nat. Hazards Earth Syst. Sci., 2, 73-82, doi:10.5194/nhess2-73-2002, 2002. 